\title{
FINANCING OF INTERNATIONAL TRANSACTIONS
}

\author{
RADU NICOLAE BĂLUNĂ, \\ PH. D. ASSOCIATE \\ DANIEL GOAGĂRĂ, \\ PH. D. LECTURER \\ UNIVERSITY OF CRAIOVA \\ FACULTY OF ECONOMICS AND BUSINESS ADMINISTRATION, \\ e-mail:rbaluna@yahoo.com \\ daniel_goagara@yahoo.com
}

\begin{abstract}
Financing (funding) is essentially the purchase of funds necessary for a business. This can be done from internal sources (company's own funds) or external (borrowed funds). The high value of goods traded in international trade makes revenues generated from internal resources not sufficient to settle the value of the goods. Thus, it is frequent to resort to borrowed funds. In International Business Transactions, external financing is done both by classical techniques of credit (credit supplier and buyer credit) and modern techniques of financing (factoring, forfeiting, leasing) all trade tailored. In terms of the length of financing, accounting funding is short-term (1-12 months) and long-term financing (over a year). In principle, export and import operations prevailing short-term financing techniques, while international investment and industrial cooperation actions are specific long-term funding.
\end{abstract}

Key-words: foreign trade, financing, loan, repayment

Clasificare JEL : M40

\section{Short-term financing techniques}

A correct financial policy has as main purpose the persuance of weight that financial funds have and the obligation in the total of resources of the economic entity ${ }^{1}$.

Short-term loans can go to pre-financing operations, being related to production activities. Other loans are strictly related to an export operation and can be granted to producers and exporters or import-export trading companies.

Pre-financing customized (specialized) loans are related to the manufacture and export of a strictly determined product. Such credits shall be granted for high value products with long manufacturing cycle. There are cases where specialized pre-financing loans are granted to exporting producers having a continuous flow of exports.

Credits aimed at facilitating research of new markets by exporters.

Advance on goods documents. In some countries, banks give loans to exporters on the basis of documents proving the existence of goods ready for export. Loan amount is proportional to the goods so pledged but not exceeding $80 \%$ of their value. Typically, these loans are granted to large exporters. A particular form of this type of loan is the loan based on warrants. The exporting company, based on mortgage goods, gives the bank a warrant which is a title of ownership of the goods and is negotiable. Therefore, banks can trade the title on the central bank.

Advance in foreign currency is equally a short-term funding technique and a method of protection against currency risk. In essence, it is the granting of a loan by a bank to an exporting company based its claim against his client abroad, untapped debt in national currency.

Bank advances through assignment of receivables. In some countries, banks provide facilities to exporters as if advances for replenishing their supplies of goods in short-term loans, by assigning claims by foreign importers. Assignment is made through a financial document disposal, under which qualify for an advance form of short-term credit to collect receivables from importers. The advance shall not exceed, as a rule, $70 \%$ of the bill.

Discount loan is one of the most used techniques in short-term financing of exports. Usually, selling on credit is accompanied by issuing a debt instrument (bill of exchange, promissory note) the importer is required to pay, at maturity, the value of the goods. Discounting is the sale of a bank title before maturity. Discount's goal is that the

\footnotetext{
${ }^{1}$ Lesconi-Frumuşanu N.M., Breuer A., Lighezan Breuer B.G., Jurchescu D., Auto financing - the main source to finance an economic entity, Annals of DAAAM for 2010 \& Proceedings of the 21st International DAAAM Symposium „Intelligent Manufacturing \& Automation: Focus on Theory, Practice \& Education”, 20-23 octombrie 2010, Zadar, Croaţia.
} 
beneficiary of a bill of exchange or promissory note from a third party claims a liquid amount without waiting for its maturity. Upon receipt of the instrument endorsed in its favour, discount bank to pay the beneficiary an amount calculated using the formula:

$\mathbf{S}=\mathrm{V}-(\mathrm{V} \times \mathrm{Ts} \times \mathrm{n}):(\mathbf{3 6 0} \times \mathbf{1 0 0})$, in which:

$\mathbf{V}$ is the value of the bill of exchange when due, including interest if applicable;

Ts is the discount rate in percent per year;

$\mathbf{N}$ is the number of days remaining to maturity.

\section{Figure 1. Running of a factoring operation}

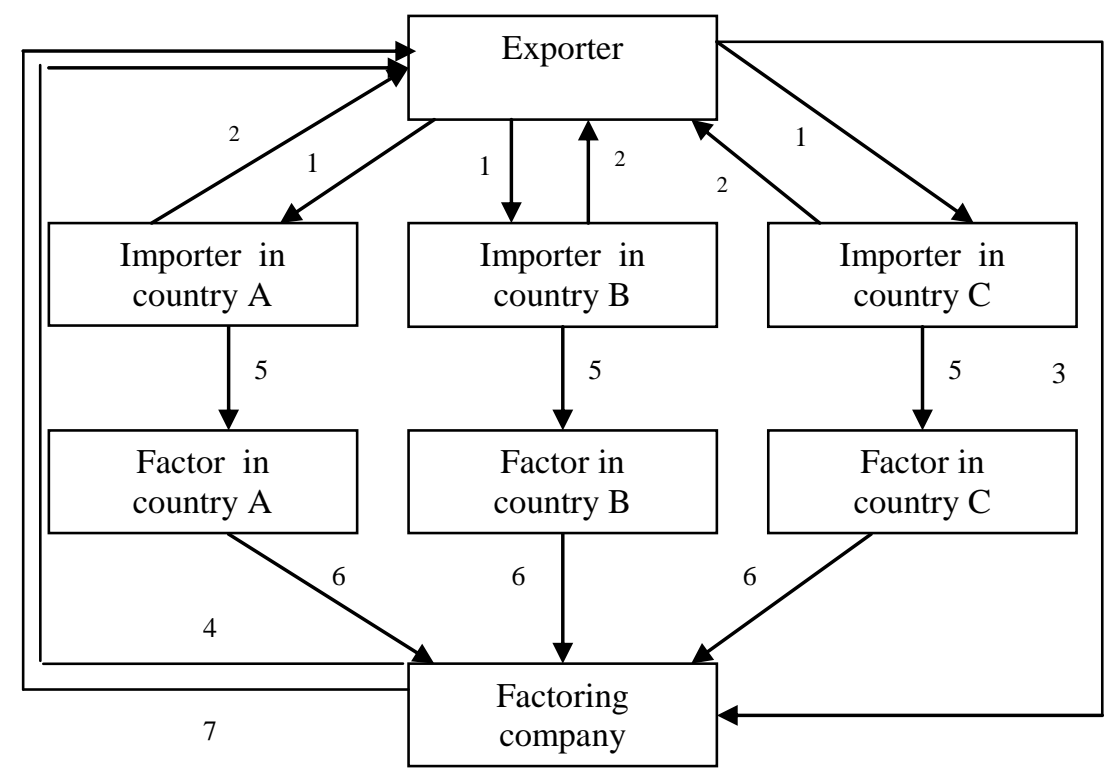

(1): delivery of goods and / or services provided by the exporter.

(2): claims against the importer.

(3): the exporter fails to receivables factoring company.

(4): factoring company will pay the exporter (adherent) $85 \%$ of the bill.

(5): recovery of the invoices from the importer.

(6): recovery of the invoices from the importer through local actors, retaining their due commission.

(7): factoring company will pay gap of $15 \%$, which will hold the equivalent of commission and interest.

Factoring is essentially a transfer of claims against third parties from the exporter to factor. The exporter receives the face value of these receivables, less commission and expenses factor. In practice, when the export factoring using immediate payment of $85 \%$ of customer bills, and the remaining $15 \%$, less the corresponding value fee and interest is charged at the time the importer pays the bill.

Lump on export credit claims is the transmission from foreign trade operations performed on specialized credit financial institution pays immediately and will recover their value at maturity of the debtor importer. Unlike input, this technique does not give the financial institution on the seller's right to appeal claim payment in case of failure of the debtor.

Forfeiting specificity is that it applies not only to short-term receivables (up to a year), but also those from export credit with medium maturity (from 1 year to 7 years). Using this technique allows achieving medium-term financing operations, thereby stimulating exports of plant, machinery and other high value products.

Forfeiting cost is higher than the discount and consists of a fixed rate, plus commission finance institution established credit worthiness differentiated by the extent to which bill (claim) is approved or not, the estimated risk of the operation, the method of payment, etc. Forfeiting, as discounting, allows recovery of amounts before maturity or conversion of credit sales a sale on the exporter.

\section{Long-term financing techniques}

The category of external financing sources includes also the bond credits, the medium and long loans, and other medium and long term debts. If we calculate the cost of these funding sources based on the preferences of economic 
Annals of the „Constantin Brâncuși” University of Târgu Jiu, Economy Series, Issue 1/2013

entities, we see that the first places are occupied by bank loans and leasing, this because of the accessibility but also because of traditionalism. ${ }^{2}$

Supplier credit is a bank loan granted to the exporter, his partner, when he agrees deferred payment for goods shipped abroad. Basically, the operation involves two distinct lending relationships:

- A merchandise credit granted by the exporter to the importer by accepting payment within a certain period after delivery;

- a cash loan granted by the bank to the exporter for export financing.

Supplier Credit is a medium or long term credit based on the grounds that, although the value of the goods delivered is high, the financial resources of the exporter allow its sale on credit. The loan provider does not exceed usually $80-90 \%$ of the value of the goods, the difference being paid by the importer in the form of advance payment or delivery.

Figure 2 is given by supplier credit financing scheme.

Figure 2. Supplier credit mechanism

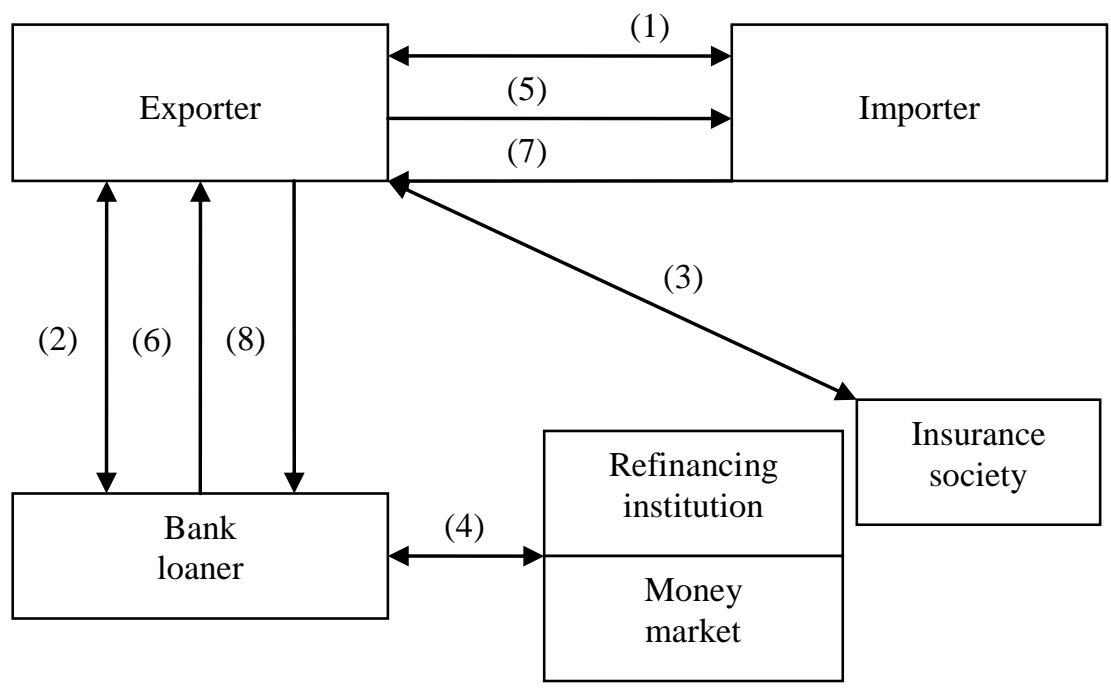

(1): commercial contract (merchandise credit);

(2): credit agreement (money loan);

(3): the insurance policy;

(4): refinancing with a specialized / money market;

(5): delivery of goods;

(6): credit (lending);

(7): payment delivery;

(8): repayment.

Most commercial banks lend money to exporters provided that they ensure their merchandise at insurance institutions. Insurance policy issued to the supplier is taken over by the bank which financed exports.

Supplier credit involves three documents: international commercial contract (export-import) credit agreement (exporter-bank) and insurance policy (insurance exporting institution).

Repayment or restitution by the beneficiary has two periods: the period of grace is not returned anything and actual repayment period.

The latter can be calculated as the average reimbursement period AP, which take into account the grace period, $\mathrm{G}$, interval between first and last installment, $\mathrm{P}$, and the interval between two successive reimbursement rates, I, all expressed in years or months.

Relationship calculation is

$$
\mathrm{AP}=\mathrm{G}+\mathrm{P} / 2+\mathrm{I} / 2
$$

The grace period is longer, the borrower is better, as the average repayment period is increasing.

Annual repayments size is the aggregate nominal value of the share of the loan and interest.

Buyer credit is a direct financing given to the importer by a bank in the exporter's country in order to allow the buyer to pay immediately the value of the goods. Buyer loans are granted, usually by banks or specialized institutions

\footnotetext{
${ }^{2}$ Breuer A., Lesconi-Frumuşanu N.M., Lighezan Breuer B.G., Jurchescu D., External financing for construction
} entities, Annals of the University of Petroşani - Economics, Universitatea din Petroşani, 2011. 
Annals of the „Constantin Brâncuşi” University of Târgu Jiu, Economy Series, Issue 1/2013

in the exporter's country export financing for this purpose an agreement ending credit the importer (or bank) and bank exporter.

If the credit provider if the exporter must be concerned with collecting its receivables to a bank in the exporter buyer credit is fully exempt funds mobilization requirements, being paid on the spot by the importer.

Loan amount ranges typically from $85 \%$ of the goods, the difference being supported in the form of advance payment or delivery by the importer. By using this type of loan, the supplier is practically fully paid on delivery.

Figure 3 shows the long-term buyer credit mechanism.

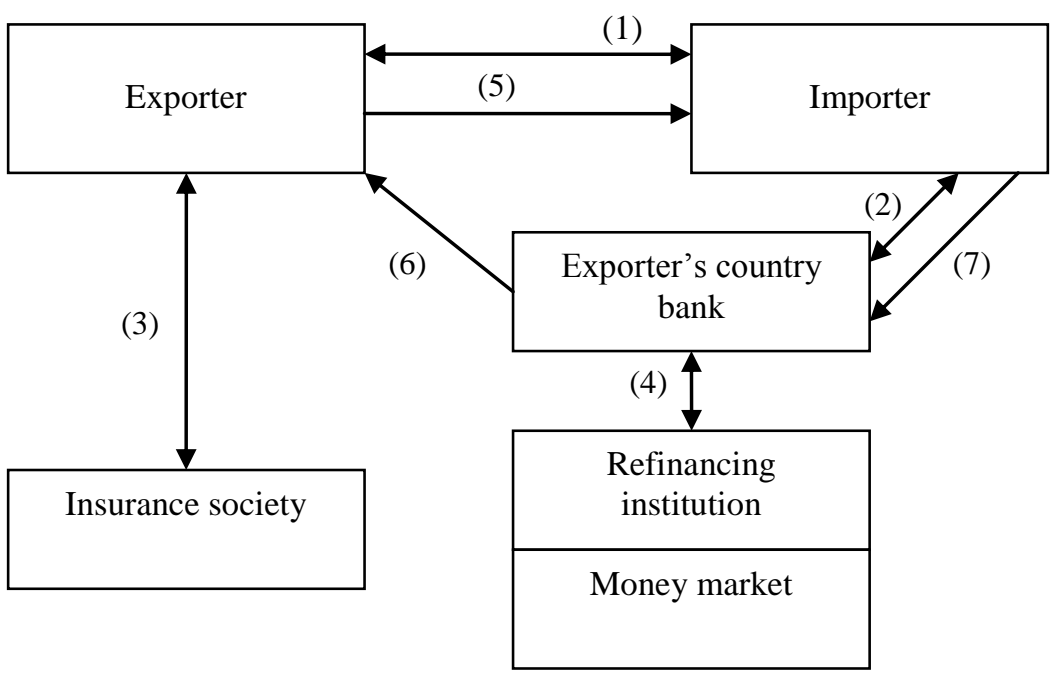

(1): commercial contract

(2): credit agreement.

(3): insurance policy

(4): refinancing

(5): delivery of goods

(6): payment

(7): repayment

Figure 3. Buyer credit mechanism

Banks granting buyer loans reunite their funds from the central bank or a financial institution through rediscount export. In case of large amounts needed in order to finance exports, banks shall mobilize funds by issuing bonds through Eurocredit or consortium loans.

Credit insurance is done by the exporter's bank at an insurance company in his country. Insurance costs are usually incurred by the importer (exporter sometimes). So for both credit and buyer there are three documents: international commercial contract (export-import) credit agreement (importer-exporter's bank), insurance policy (exporter's bank-insurance institution).

Leasing consists of renting of equipment goods made by specialized financial companies (leasing companies) to the companies (beneficiaries) who have no equity or are unable or unwilling to use bank loans to buy them from manufacturers.

Leasing involves basically two contracts: one for the sale concluded between the producer, the seller, and the leasing company, who credited a lease as a buyer and a tenancy agreement between the leasing company and a third party beneficiary. Operation is initiated rental company wishing product that addresses this leasing company with a call for tenders. The leasing company, following acceptance of the application, proceed to establish contact with the manufacturer requested to purchase his property; the parties involved in this process are the leasing company and the prospective beneficiary. After the conclusion of the leasing contract and the purchase of property by the leasing company the goods are released to the beneficiary.

As shown in the above, the leasing transaction involves three stages: contracting, buying, leasing (see Figure 4).

For the use of the goods, the beneficiary will pay the cost to leasing company in the form of installments over the period of the contract. Usually, at the end of the rental period, the beneficiary has a triple option: to extend the contract, to abandon, to buy the asset at its residual value.

In Romanian law, leasing is defined as the operation by which one party, called the lessor/financier, transmits for a specified period the right to use an asset whose owner it is to other Party, the user, upon request, against periodical payment called leasing rate. At the end of the lease, the lessor/financier shall respect the right of the user to purchase the asset, extend the lease or to terminate the contractual relationship. 
Figure 4. Leasing transaction phases

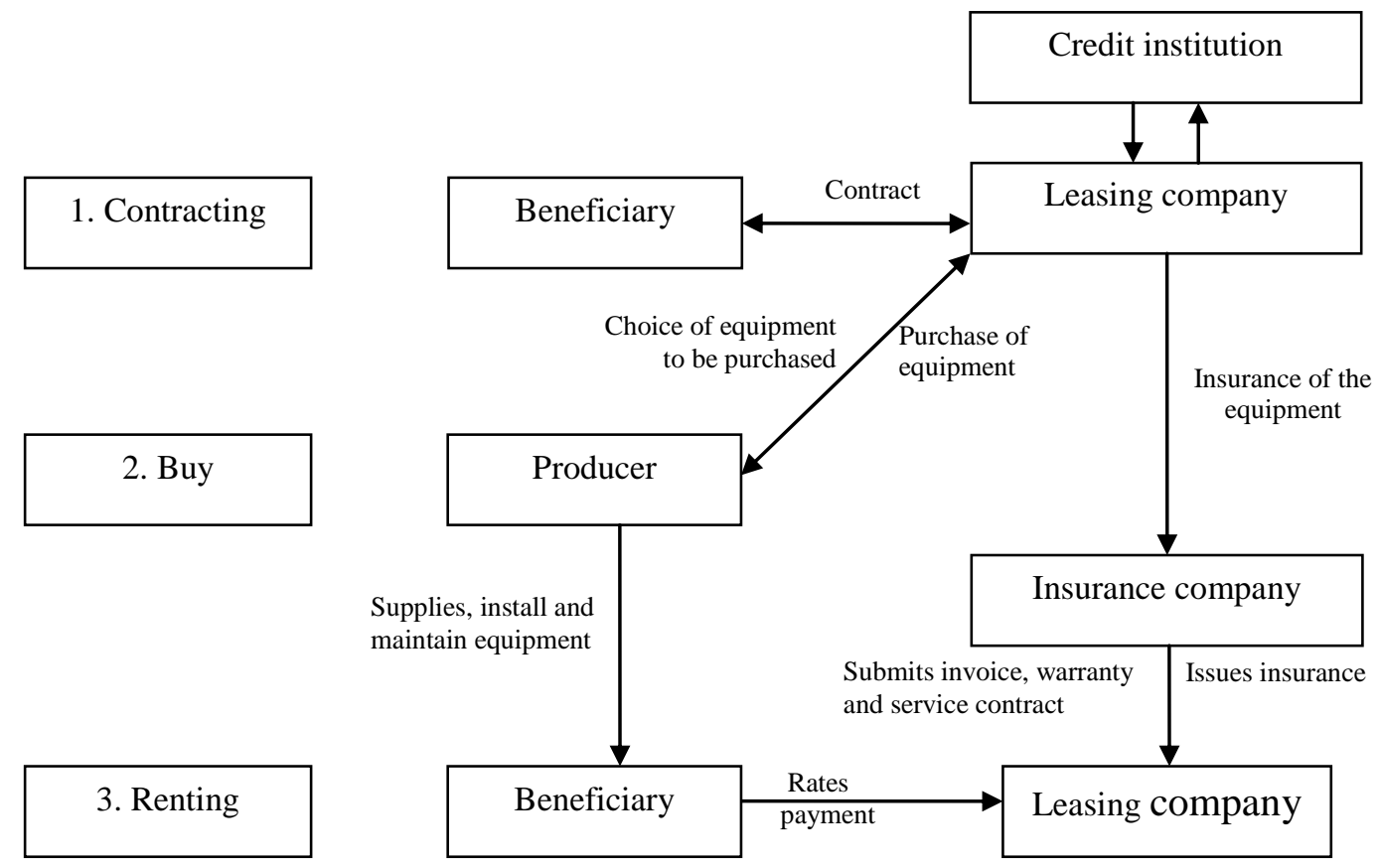

\section{Conclusions}

Short-term financing is aimed at providing means of payment for the exporter who sold goods on credit, then looks forward to recover export value from the importer over a period up to one year. Medium and long term financing is specific to high-value exports, or complex export as some forms of industrial cooperation. This can be achieved by classical techniques of credit (supplier credit and buyer credit) or by financing techniques such as leasing.

Often, the loan amount is depends on export value, so exporting producers are eligible for credit only if the value of exported goods reaches a minimum value of bank default. Commercial banks, in turn, are able to refinance, to complete the funds from the central bank or other institution specializing in financing exports from their country.

Besides trade effects, the use of factoring in international transactions has a number of advantages: eliminates the risk of default and currency risk; ease cash-flow problems, simplify business management, enables the use of bills of exchange or letter of credit for payment; removes misunderstandings that may arise lack of knowledge of the laws and usages of the importing country.

On the other hand, international leasing operations have gained ground lately, especially for high value goods (equipment, vehicles, machinery, heavy mechanical materials and so on). Leasing included also real estate, renting covering for industrial or commercial buildings, administrative buildings.

\section{Bibliography:}

1. Bălună R. - Contabilitatea comerţului exterior, Editura Universitaria, Craiova, 2009.

2. Breuer A., Lesconi-Frumuşanu N.M., Lighezan Breuer B.G., Jurchescu D. - External financing for construction entities, Annals of the University of Petroşani - Economics, Universitatea din Petroşani, 2011.

3. Lesconi-Frumuşanu N.M., Breuer A., Lighezan Breuer B.G., Jurchescu D. - Auto financing - the main source to finance an economic entity, Annals of DAAAM for 2010 \& Proceedings of the 21 st International DAAAM Symposium „Intelligent Manufacturing \& Automation: Focus on Theory, Practice \& Education”, 20-23 octombrie 2010, Zadar, Croaţia.

4. Pîrvu C., Bălună R., Mangra M. - Contabilitatea tranzacţiilor internaţionale - suport de curs pentru I.D., Editura Reprograph, Craiova, 2009.

5. Popa I. - Tranzacţii de comerţ exterior, Editura Economică, Bucureşti, 2002. 